\title{
Investigating TESOL Teachers' Awareness of Critical Pedagogy at Higher Education Institutions in Oman: Implications for Critical Professional Development
}

\author{
Thuraya Al Riyami \\ English Language Center, Ibra College of Technology, Oman
}

\author{
Ali Al-Issa \\ College of Education, Sultan Qaboos University, Oman
}

\section{Introduction}

There has recently been a growing interest in viewing the learning of English as a complex sociopolitical process which cannot be achieved through the mainstream teaching methodologies in which the student's role is marginal and the teachers are consumers of Anglo-American materials (Norton \& Toohey, 2004; Kumaravadivelu, 2011). Thus, Critical Pedagogy (CP) has been viewed as one of the alternative pedagogies capable of meeting the demands of the complexity of English Language Teaching (ELT) within its sociopolitical context (Canagarajah, 1999; Norton, 2000; Penneycook, 2001; Norton \& Toheey, 2004; Akbari, 2008). Although CP is not an easy philosophy to define, it is mainly

A perspective on teaching, learning, and curriculum that does not take for granted the status quo, but subjects it to critique, creates alternative forms of practice, and does so on the basis of radical theories of language, the individual, and society that take seriously our hopes for improvement in the direction of goals such as liberty, equity, and justice for all (Crookes, 2013, p.1). 
It can be hence said that $\mathrm{CP}$ is "an educational response to oppressive power relations and inequalities existing in educational institutions" (Keesing-Styles, 2003, p.2).

\section{CP in TESOL}

Although CP has been around as an educational approach for almost six decades, it has been a feature of Teaching of English to Speakers of Other Languages (TESOL) in some contexts for only two decades (Canagarajah, 2005a, 2005b). This can be attributed to "the relatively strong hegemony of mainstream and apolitical approaches" (Troudi, 2015, p.89) to TESOL and the heavy reliance of teacher education programs, including both pre-service and in-service, on formal and methodological issues (Cox \& Peterson, 1999; Haque, 2007; Byean, 2011). In addition, one of the reasons for the delay in CP's arrival in ELT is the hegemony of the banking model in TESOL in particular and education in general in most contexts. Mohamed and Malik (2014), via interviewing ten teachers, found that ELT teachers lacked awareness of CP in five different countries (Sudan, Iran, Pakistan, India, and America) because of the banking concept of education operated in the institutions where they worked. The teachers' role is limited to a "conduit" for "channeling the flow of information from one end to the other" (Kumaravadivelu, 2011, p.8). Therefore, teachers are unable to critically think about the ideological and political aspects of TESOL.

However, CP has recently started gaining momentum in TESOL and has been applied broadly in different parts of the world where teachers transfer the principles and appropriate them according to their contexts. It has been emerging via various branches including 'critical literacy', 'critical multiculturalism', 'critical language awareness', and 'critical language test'. For this study, all these branches are subsumed under the term $\mathrm{CP}$ since they reject technicality in dealing with TESOL and work against the banking model of education critiqued by Freire (2000, 2003).

When teachers endorse $\mathrm{CP}$, it affects the way they view learning and teaching, and the way they perceive the curriculum. For example, teachers who believe in CP reject the belief that the goal of TESOL programs is to help students to master the language and pass exams in an era characterized by 'teach to the test' (Gruenewald, 2003). They believe that the purpose of TESOL programs is to enable students to master the language in conjunction with raising their consciousness of the world around them. For instance, Benites (2012) maintains that, within the CP framework, a TESOL program should have three aims. First, it should improve students' communicative skills and abilities. Second, it should raise students' awareness of the world. Third, it should embolden students to act in order to ameliorate their situations. 
In addition, $\mathrm{CP}$ emboldens teachers to question the TESOL materials that are produced in the center and reach the periphery in full packages, as is the case in Oman (Tanveer, 2013; Al Jadidi, 2009), for example. Many studies have shown that many current TESOL materials have marginalized learners' interests, feelings, experiences and perceptions (Shin \&Crooks, 2005; Derince, 2011; Chi, 2011). What is more, most of the current materials used in TESOL seem to avoid discussing critical issues "such as crime, corruption, economic exploitation, racism, modern slavery" (Troudi, 2015, p.93). Unfortunately, these materials continue to address artificial topics including family, hobbies, food, sport and travel (Troudi, 2015; Moorhousem, 2014; Banegas, 2011). This necessitates teachers to play their role in modifying TESOL materials to address students' needs and concerns and to raise their awareness of critical issues surrounding them.

In addition, most textbooks do not represent the status of English as an international language (Caukill, 2011) and highlight American and British varieties as standards that indigenous learners should meet; this is true of Oman and many other Arab countries, for example. However, the international status of English means its ownership does not belong to the center, but to everyone who speaks English (Norton, 2000). TESOL teachers need to understand that by emphasizing center standards, they are perpetuating Western hegemony and marginalizing other varieties of English. From a CP perspective, English learners "have to develop sensitivity to more than one variety of English" (Kachru \& Smith, 2008, p. 182).

Furthermore, CP requires TESOL teachers to engender a positive classroom atmosphere that enhances "student self-esteem and reduces anxiety levels" (Peterson, 2003, p.372). In addition, CP entails that teachers legitimize students' voices and respect their choice of topics or methodologies. Various techniques can be implemented by TESOL teachers in order to give their students a voice in the classroom. This can be introduced at the beginning of the year by negotiating classroom policies and the syllabus to meet students' needs and can include content, modes, and ways of working (Ooiwa-Yoshizawa, 2012; Mack, 2012; Mencke, 2010; Sadeghi, 2008). Furthermore, teachers can occasionally ask students to reflect on what is helpful or unhelpful during the class and adjust their teaching accordingly (Shor, 1996; Mazier, 2014).

From CP's perspective, students' first language can be utilized to enhance dialogue if they are not proficient (Canagarajah, 1999; Kumaravadivelu, 2003; Akbari, 2008). This is because utilizing students' first language in the TESOL classroom eliminates students' feelings of inferiority and marginalization because they can use their first language, which is part of their own identity, to give them voice and power (ibid).

Thus, TESOL teachers should be aware of the usefulness of using students' first language in facilitating English learning, especially as there is no empirical 
confirmation that students' first language hinders the acquisition of English. On the contrary, students' usage of first language can facilitate students' English proficiency. However, this is not to say that L1 should be used entirely in the TESOL classroom; it should be employed in a way that facilitates the process of learning English.

The shift toward viewing learning English as a social and political enterprise has resulted in the occurrence of critical language testing (Lynch, 2001), which is also an area of inquiry located within $\mathrm{CP}$, of which teachers need to be aware if they want to approach their teaching critically. Thus, CP rejects a one-time pencil and paper test (Byean, 2011; Ismael, 2013). CP emphasizes the necessity of utilizing alternative assessments including portfolio assessments, group projects and performances and essay examinations that tackle critical thinking (Shor, 1992, p.144). It also emphasizes the necessity of studying the consequences of these tests on students, teachers, institutions, and society as a whole.

\section{ELT Teachers' Awareness and Attitudes towards CP}

Several studies scrutinized teachers' awareness of CP (Sadeghi \& Ketab, 2009; Safari \& Pourhashemi, 2012; Byean, 2011; \& Baladi, 2007). The majority of these studies revealed that many ELT teachers are not aware of CP as an approach that can be used in ELT. Nevertheless, after being introduced to CP, teachers experienced frustration since they found themselves powerless against demands for regulations, increased bureaucracy, and accountability (Abednia, 2012; Pishghadam \& Meidani, 2012). For instance, Lin (2004) revealed, through introducing $\mathrm{CP}$ in an MA program in Hong Kong the difficulties of achieving critical consciousness in a context where room for "democratic condensation and alternative practice is limited" (p.277) as it is the case in Oman and many developing countries. Thus, introducing CP to teachers did not lead to critical awareness to motivate them to resist oppression and take action towards changing the status quo. Lin concluded that while introducing CP has "helped teachers to see the sources of their oppression under the current school administration system, they remain just that" (p.279). Lin also highlighted that her participants encountered a lot of difficulties trying to make sense of the abstract language of $\mathrm{CP}$, which made them feel frustrated with the reading course. She concluded that critical pedagogues need to be cautious when they introduce CP to school teachers, otherwise "their theories run the risk of talking over their heads" (p.276). Therefore, it is necessary to introduce $\mathrm{CP}$ in a way that empowers teachers, not to disempower them by presenting abstract terminologies.

Baladi (2007) investigated the possibility of implementing CP in a multicultural ESL classroom in a Canadian private language school. Via using critical action research, she focused on four teachers who were teaching at various levels. The results showed, in the first phase of the study that teachers were not 
familiar with $\mathrm{CP}$ and tended to base their teaching on mainstream topics. Furthermore, they viewed their role as teaching English skills without motivating their learners to question their social practices. Phase two comprised the intervention, where the four teachers were asked to teach two lessons based on $\mathrm{CP}$ principles that the researcher designed. The researcher used post-lesson interviews and focus groups to tackle teachers' responses to teaching through CP. Baladi (2007) concluded that the participants became enthusiastic about basing their teaching on CP. However, they described many challenges which teachers might face when they implement $\mathrm{CP}$, including striking a balance between teaching students critically and addressing students' linguistic needs and preparing them for tests that are crucial to their success in life.

Garcia-Gonzalez (2000) examined four elementary teachers' attitudes and practices regarding $\mathrm{CP}$ in two urban public schools in California (USA), and used multiple methods including teachers' interviews and classroom observation. The results showed that teachers' conceptualization of $\mathrm{CP}$ varied, including raising students' awareness of identity, race and culture, teaching through the students' experiences and incorporating student-centered approaches. With regard to teachers' practice of $\mathrm{CP}$, the results showed that they implemented $\mathrm{CP}$ through establishing dialogues with students, utilizing problem posing models to facilitate reflection, showing respect to students' native language and including students' life experiences in the syllabus. However, teachers encountered some challenges including "planning time, collegial support and teaching resources" (p.12).

Ko and Wang (2009) examined three English language teachers' attitudes towards implementing CP in ELT in Taiwan colleges. Semi-structured interview and lesson plan analysis were utilized to collect data for the study. The findings of the study revealed that the participants showed enthusiasm towards CP. Nonetheless, they expressed some concerns about CP including students' language proficiency and teaching resources.

Sadeghi and Ketab (2009) investigated six teachers' attitudes towards CP in Iran. After introducing CP to them through extensive reading on $\mathrm{CP}$, onlineforums, opinion-exchange and reflection for a whole year, teachers were asked via interviews about their understanding of $\mathrm{CP}$, its applicability in the classroom and the challenges they faced when they incorporated its tenets in their teaching. The results showed that the in-service course had a great impact on constructing a new perspective on teaching. Nonetheless, the participants also expressed that they encountered challenges, including Iranian learners being unprepared for such a critical approach and the teachers' inability to move from technicality in their teaching.

Noroozi Siam and Soozandehfar (2011), Aliakbari and Allahmoradi (2012), Safari and Pourhashemi (2012) and Sahragard, Razmjoo and Baharloo 
(2014) surveyed the Iranian teachers' attitudes towards CP and its practicality in the educational system. The results showed that teachers were in full agreement with and approved of CP. However, a number of obstacles, namely lack of knowledge about CP, centralized top-down educational management, absence of a culture of critical thinking in Iranian education, resistance of school administration to any innovative approach, and a lack of critical materials worked against implementing $\mathrm{CP}$ in Iranian ELT.

\section{The Context}

The Higher Education (HE) system in Oman has grown rapidly over the past three decades, especially since the establishment of the first HE institution in Oman, SQU in 1986 (Al Shmeli, 2011). This expanding growth of HE institutions corresponds to the necessity of producing qualified Omani citizens who are capable of participating in the ongoing development of Oman (Al-Jardani, 2014). Every year thousands of Omani students join HE institutions to continue their first degrees where English is used as a Medium of Instruction (EMI). These students aim to develop their English because it is considered the gatekeeper to technology, white-collar jobs, and modernity (Al-Jadidi, 2009; Al-Jardani, 2011; Al-Issa, 2014). Additionally, English in Oman is a global lingua franca and serves important purposes like inter-lingual communication, cultural analysis and understanding, pursuing higher education and conducting business (Al-Issa, 2015).

There is thus a huge shift in students' life when they join HE institutions, as here they start to learn in English as opposed to learning about English. Thus, 88\% of the students who join tertiary education start by taking intensive English programs that prepare them to study their specializations in English (Al Shmeli, 2011). Students who fail to pass English courses are dismissed from HE institutions even before they reach the specialization stage. Thus, it can be said that English plays a major role in deciding Omani students' future in HE institutions ( $\mathrm{Al}$ Hajri, 2013; Al-Jardani, 2015).

Therefore, the first experience of Omani students at the tertiary level is of receiving instruction in English language at the English Language Centre (ELC) run by $\mathrm{HE}$ institutions in order to enable them to join their specializations. This means that the ELCs receive students who have just graduated from high school, so these ELCs should act as a critical transition stage to prepare students to join the new phase in their lives. The importance of this first university year was emphasized by Bosman, Dedekorkut and Dredge (2012): "the first year experience of a university student is significant. It can make or break a student and sets the tone for the remainder of their academic journey and their career path" (p.8). Thus, it is important for these ELCs to establish learning and teaching approaches that shift the role of students from passive receivers of information to active and 
dynamic learners through problem posing and dialogue about topics related to their lives.

In his study of the role of ELCs in the bridging year between secondary school and university, Al-Hussaini (2006) found that Omani students criticized the merely technical role of English language teachers who just taught them without dealing with them as people or helping them to truly engage in this transitional life stage. He concluded that the traditional methods currently utilized in ELCs at tertiary level do not promote students' active involvement in the most important stage in their life which, we contend, is to prepare them for being effective agents of change in their society.

Most Omani HE institutions depend on imported TESOL materials, mainly from the UK and the USA (Al-Jadidi, 2009; Ismail, 2011). Most of these teaching materials include full packages consisting of textbook, workbook, teacher's guide, charts, audio and videotapes and compact discs. However, these teaching materials often present topics that do not correspond to Omani students' concerns or interests (Al Mahrooqi\& Al Busiadi, 2010; Al Mahrooqi et al., 2015). Tanveer (2013) asserted that the content of these textbooks added barriers to learning English since students made a lot of effort to comprehend concepts that did not relate to their context. He strongly recommended that HE institutions think seriously about contextualizing the learning of English for it to be effective.

Many studies criticized the traditional methods implemented by English language teachers in Oman (McLean, 2011; Al-Mahrooqi, Hassan \& Asante, 2012; Al-Mahrooqi, 2012; Tanveer, 2013). The current literature is talking about an "awakening" period in the TESOL field (Kumaravadivelu, 2006) which is characterized by moving beyond methods of teaching English to approaches where teachers are teaching for social transformation. While the literature about the TESOL system in Oman has focused on the necessity of implementing a communicative method of teaching English (Al-Husseini, 2006; McLean, 2011; Al-Mekhlafi \& Ramani, 2011), the critical stance is almost absent from discussions of ELT in Oman (Al-Issa, 2015). Thus, there is a pressing need to revolutionize the TESOL system in Oman in order to overcome the challenges facing the country including globalization and the advance of knowledge and technology (Al Nabhani, 2007) where English is used as the main global language. Moody (2012) argues that this status of English calls for changes in approach, methodology, curriculum, and overall perceptions. In addition, Al-Issa (2007) asserted that "times have changed and so have the reasons and purposes for learning English and the way through which it is learnt" (p.213).

The Arab World, where Oman belongs, has been facing radical events since December 2010 which are widely known as the "Arab Spring". There has been a revolutionary wave of demonstrations and protests that exemplify civil resistance against misuse of power and disempowerment of the people, hegemony, 
marginalization, subordination, oppression and suppression, and injustice. It is worth mentioning that university and college students constituted the biggest group in these demonstrations in Oman (Al-Hajri, 2013). These young adults who crowded into the streets calling for political, social, and economic improvement were criticizing corruption and power misuse at all levels in their societies and resisting the oppressive political, social, and economic conditions. Through their protests, they held a hope for justice and amelioration and believed in their ability to struggle in order to achieve transformation and reform in their societies.

One of the main demands of those underprivileged people has been to improve the quality of education in HE institutions, which ELT education is a fundamental part of. There is a pressing need to have an educational system that reflects the hoped-for social, political, and economic changes. Therefore, we believe it is necessary to implement a pedagogy that aims to raise students' consciousness of dominant ideologies by confronting and interrogating these ideologies as a first step toward transformation. Thus, one aim of this study is to investigate TESOL teachers' awareness of $\mathrm{CP}$ at tertiary level in Oman, because "the teacher is the ultimate key to educational change and school improvement" (Hargreaves, 1994, p. ix). Another aim is to introduce a new research direction to the Omani ELT research (Al-Issa, 2015) to provide a fresh perspective about the theories and practices of ELT in an ideologically-imbued and rigidly controlled and centralized, hegemonic, and unjust ELT system like the Omani one, where students' and teachers' responsibilities outnumber their rights by miles and where implicit and explicit policies drive and shape teachers' theoretical and practical knowledge (Al-Issa, 2015).

\section{Method}

\subsection{Research Questions}

In light of the aforementioned discussion, this study aims to answer the following research questions:

1. To what extent are the TESOL teachers at the ELC of four HE institutions aware of $\mathrm{CP}$ ?

2. What are the perceptions of the TESOL teachers at the ELC of four Omani HE institutions about the teaching and learning of the English language within the CP approach?

3. What are the perceptions of the TESOL teachers at the ELC of four HE institutions about the curriculum of the English language within the $\mathrm{CP}$ approach?

4. What implications do the study findings have for the TESOL teachers' professional development? 


\subsection{Participants}

This study followed a convenience sampling approach, which depended on geographical and time availability and easy accessibility to the researchers. Table 1 illustrates the exact number of participants from the four institutions:

Table 1: The Participants of the Questionnaire from the Four Institutions

\begin{tabular}{llll}
\hline Institutions & $\begin{array}{l}\text { Total number of } \\
\text { ELT teachers }\end{array}$ & $\begin{array}{l}\text { Number of } \\
\text { Questionnaire } \\
\text { respondents }\end{array}$ & Percentage \\
\hline Institution 1 & 86 & 41 & $48 \%$ \\
Institution 2 & 130 & 50 & $39 \%$ \\
Institution 3 & 110 & 60 & $55 \%$ \\
Institution 4 & 80 & 33 & $41 \%$ \\
Total & 406 & 178 & $44 \%$ \\
\hline
\end{tabular}

The TESOL teachers in these four institutions who responded to the questionnaire were of various nationalities, including many Indians (31.5\%), some Filipinos (10\%), few Pakistanis, few Arabs (Omanis, Jordanians, Tunisians and Sudanese) and very few Canadians, Americans, British, Australians, South Africans and Europeans. It is worth mentioning that the small number of Omani TESOL teachers reflects the situation in many HE institutions. The majority of the participants $(73.6 \%)$ were Master's degree holders. However, some held a Bachelor degree and others had a Ph.D.

\subsection{Ethical Considerations}

Prior to choosing institutions to participate in the research, the researchers obtained permission from the Ministry that supervised the four institutions. After gaining the Ministry's permission, Deans of Colleges and Heads of ELCs were contacted in person and the aims, method, procedures and benefits of the study were elucidated in full detail. We then obtained the second consent of the participants. We assured them that their reactions toward the research and the data collected from them would by no means affect their jobs, especially in some cases where the participants' opinions seemed to be contradictory to the authorities' views in the context.

Therefore, all the data gathered was dealt with anonymously and with no reference to any particular participants. This was achieved by assigning numbers to individuals who filled in the questionnaire. In addition, all data - from the 
questionnaires were securely stored in a locked cabinet. Digital data were kept on a computer with a username and password only known by the researchers.

\subsection{Data Collection and Analysis}

The final version of the questionnaire (see Appendix 1) consisted of three parts. The first part included questions on background, such as education level, gender and nationality. The second part contained open-ended questions on awareness and implementation of CP. The third part consisted of items with a fivepoint Likert scale for responses ranging from "totally agree" to "totally disagree". 22 items were distributed among two general themes (curriculum and teaching and learning of the English language), which are inspired by the pertinent literature and which investigated teachers' awareness of $\mathrm{CP}$ as a possible approach in TESOL.

With regard to the closed-ended questions in part three and open questions one in part two in the questionnaire, they were entered into the SPSS program after they had been numbered and coded using a nominal scale for part three of the questionnaire and ordinal scale for open question in part one. Descriptive statistics, including means and standard deviations, were utilized.

Nonetheless, the rest of the open-ended questions in part two were analyzed qualitatively. This step involved assembling the data, which comprised 34 questionnaires (The total number of questionnaires where teachers answered the open-ended questions). Within this step, we continued reviewing the research questions and going through the transcribed data, looking for broad patterns, ideas or trends that seemed to answer the research questions.

\subsection{Rigor}

To ensure its content validity, the initial version of the questionnaire was revised by two research experts and modified on the basis of their feedback. In addition, the questionnaire was given to four experienced TESOL teachers who had been working in Oman for more than seven years. This feedback was considered in terms of wording, layout, and content.

\section{Results and Discussion}

\section{Research Question \#1: To what extent are the TESOL teachers at the ELC of the four Omani colleges of technology aware of CP?}

The analysis of this question revealed that most of the teachers were not aware of $\mathrm{CP}$ as an approach for teaching and learning. 


\section{Figure 1: ELT Teachers' Awareness of CP}

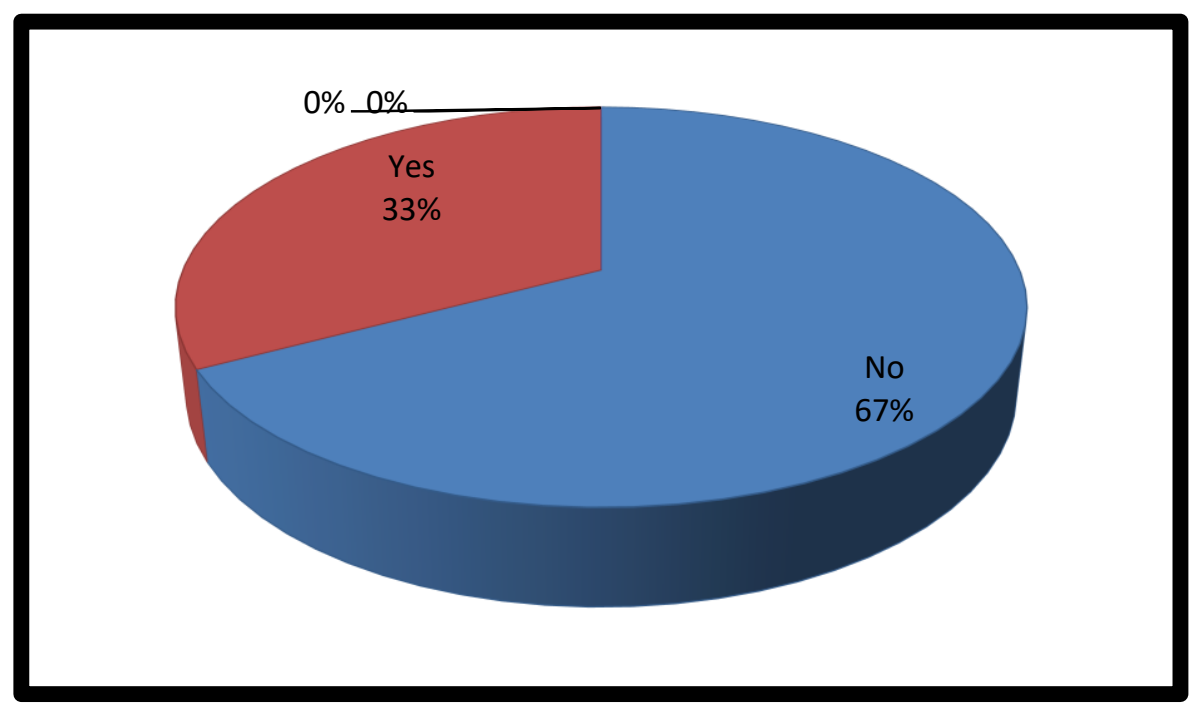

Figure 1 shows that $67 \%$ of the TESOL teachers who participated in this study were not aware of CP, while only $33 \%$ of them had heard of it through various resources, including their graduate studies, conferences, articles, and the Internet. This is in line with other studies by Cox and Assis-Peterson (1999) and Baladi (2007), which found that TESOL teachers were unaware of CP. Teachers' unawareness of CP could be attributed to the fact that after joining the profession, most teachers are less likely to read about current philosophies and approaches in teaching due to several reasons including teachers' heavy workload, which can be considered as a challenge.

Teachers hence need to read more about current approaches in TESOL. For instance, teachers can read more about $\mathrm{CP}$ which is gaining momentum in the recent decades. Thus, the study recommends that they start to read a book by Wink (2005) entitled Critical Pedagogy: Notes from the Real World, which is considered to be an essential introduction to what $\mathrm{CP}$ is all about and a practical manual of how to put it into practice. There are also many publically accessible publications by major authors and teacher educators available online, including articles, presentations, research papers, and recordings on YouTube.

One teacher wrote:

Teaching through CP means a lot of preparation time. So, teachers need to be willing to take their work home in order to prepare good materials, which cannot be done inside the college because of the teaching load teachers have. 
Regular meetings should be thus organized between teachers, experts, and administrators in order to keep track of the kinds of challenges TESOL teachers might encounter so that ongoing support can be provided for them. To give concrete examples of how to handle such meetings, ELCs' teachers are required to conduct meetings with each other from time to time or on a regular basis where they can discuss concerns and issues (Al-Lamki, 2009).

Another reason can be the rigid exam and textbook-based system that has dominated the Omani TESOL system for the past five decades or so. One of the teachers asserted that he had implemented CP in his country, but had been unable to do so since Oman "seems a pretty much rigid place for revolutionary ideas", which points in the direction that neither times have changed in Oman nor have the reasons and purposes for learning English and the way through which it is learnt due to administrative resistance to innovation. This is despite the awakening the TESOL field and the Sultanate of Oman have been witnessing. Al-Issa (2014) maintained that the current rigid TESOL system in Oman "slams the door in the face of change, creativity and innovation" (p.415). One can read frustration and feeling of powerlessness in this teacher's statement. Using contradictory concepts like "rigid" and "revolutionary" indicate this teacher's feeling of absence of space for introducing change due to the controlled nature of curriculum implementation.

Thus, teachers can cooperate with their colleagues who are also interested in $\mathrm{CP}$, and share their ideas and concerns to strengthen their knowledge about $\mathrm{CP}$. Braa and Callero (2006) maintain that CP could be best implemented if cooperation among teachers in any institution is established.

In addition, the in-service professional development programmes that aim to raise teachers' awareness of current teaching approaches in these colleges are very rare and depend more on availability than on the actual needs of the TESOL teachers (Ismail, 2011; Al Jadidi, 2009). Friere (1970) encourages setting and participating in critical teacher study groups in order to raise critical awareness because it can "enable teachers to become subjects of the educational process by overcoming authoritarianism and an alienating intellectualism" (p. 74). Knowledge in these study groups is meant to be constructed, shared, and exchanged equally to help raise teachers' awareness of critical pedagogy and thereby enrich the field of ELT. Professional discourse in these problem-posing and social-justice oriented study groups focuses on using ELT education "as a vehicle for equity and justice" (Kohli, Picower, Martinez, \& Ortiz, 2015, p. 22) and resistance of the reproduction of inequality.

Adding to this, teachers at the four HE institutions have very limited opportunities to participate in international, regional, or even local conferences, due to administrative and financial reasons making it hard for them to keep abreast of the latest trends in TESOL. Hence, establishing a unit for (critical) professional 
development, especially as such a unit is absent from the colleges of technology, can play an important role in valuing teachers' creativity and critical thinking skills and engaging them in a professional agency that meets their needs of social justice with "transformatory goals" (Kohli, Picower, Martinez, \& Ortiz, 2015). Such a unit can also assist in identifying teachers' needs and concerns, designing professional development programmes that suit such needs, and developing critical awareness of the current approaches in TESOL.

Another teacher was aware of $\mathrm{CP}$, but preferred not to use it due to its technical and political nature, which he implied contradicted with the values and principles in Oman. He said

I did not use it because not everyone wants to be 'set free'. It is a western assumption based on the 'enlightening', and critical pedagogy has its own set of problems surrounding issues of emancipation and freedom.

This finding is in line with that reported by Al-Hussainin (2006) about the adherence of teachers at the ELCs to the traditional methods and their failure to deal with their students as people in need of transition to act as effective agents of change in their society. This teacher is resisting teaching for transformation, which brings about positive change as well as emboldens students and ameliorates their situation.

From this teacher's perspectives, and as argued by Lin (2004), CP entails abstract terminologies like "set free" and "enlightening", which can go over students' heads. CP aims to liberate students and give their voice supremacy, power, and legitimacy. However, this teacher believed CP might not bring about change in a non-western society like Oman with a centralized and top-down TESOL educational system that has promoted the hegemonic banking model and established and maintained its powerfully dominant non-democratic culture for over four decades. This is in line with the work of O'Mochain and Perkins (2010), who found that teachers had sometimes imposed CP on students who preferred to be taught through mainstream methods and to discuss less critical topics.

Although CP challenges the banking model of teaching, it has its own limitations, especially regarding its philosophical and idealistic assumption of the possibility of emancipation and radical change, which might not be achievable (Neumann, 2013). Hence, teachers avoid using it in their classes and perceive teaching through it to be problematic. Since the four ELCs have many expatriate TESOL teachers who may not be familiar with the Omani culture, which is essential to implement $\mathrm{CP}$, ongoing supportive orientation programs are needed for those teachers. Such programs can include cultural nights or events, group trips to certain Omani places where Omani culture can be introduced to them, and hosted lunches or dinners for those TESOL teachers. Such cultural activities will play a 
role in familiarizing TESOL teachers with the Omani culture, creating a more collegial atmosphere at the ELCs, which can crucially and positively affect teachers' motivation to play their role as agents of change. For the long-term goal, the Omani government should work hard to encourage Omanis to become qualified TESOL teachers, so that 'Omanization' can be achieved in higher education, as contracted expatriate teachers are less motivated to initiate change or innovate to ameliorate the society.

Interestingly, there was a minority of teachers who reported that they were aware of CP as an approach that could be used in TESOL, but who only applied it in their teaching in a limited way to help improve their students' communicative abilities. One teacher wrote:

I only implemented it in a limited way here in Oman. Sometimes, I ask my students to give their own critical thoughts and conclusions about particular topics, which helps them in promoting their communication skills.

This finding contradicts that reported by Al-Hussaini (2006) about the failure of teachers in the ELCs to help students to engage in a transitional life stage and promote students' active involvement through the use of traditional teaching methods to help them develop as agents of change in their societies. This teacher is aware of the challenges $\mathrm{CP}$ brings to a context like the Omani ones. He, therefore, introduced it carefully and through engaging students in using communicative English and critical thinking skills to help empower them, rather than frustrate and disempower them by presenting abstract terminologies that could go over their heads.

Research Question \#2: What are the perceptions of the TESOL teachers at the ELC of four HE institutions about the teaching and learning of the English language within the $\mathrm{CP}$ approach?

Table 2: Teachers' Perceptions of Teaching and Learning

\begin{tabular}{|c|c|c|}
\hline Statement & Mean & SD \\
\hline $\begin{array}{l}\text { 1. The role of the ELT teacher is to transfer the language to the } \\
\text { students. }\end{array}$ & 4.11 & .84 \\
\hline $\begin{array}{l}\text { 2. Policies and rules should be set by the teachers and students } \\
\text { should follow them. }\end{array}$ & 3.63 & 1.08 \\
\hline 3. Students are receptive to what the teacher is telling them to do. & 3.52 & .84 \\
\hline 4. A good student is the one who obeys rules. & 3.49 & .80 \\
\hline $\begin{array}{l}\text { 5. Students can decide for themselves what to learn in an ELT } \\
\text { course. }\end{array}$ & 2.71 & .94 \\
\hline $\begin{array}{l}\text { 6. The ELT teaching in my college is based on communicative } \\
\text { English teaching approach. }\end{array}$ & 3.86 & .78 \\
\hline 7. English should only be taught through English. & 4.32 & 1.13 \\
\hline 8. Arabic usage in the classroom hinders students' exposure to & 4.20 & .74 \\
\hline
\end{tabular}




\begin{tabular}{|c|c|c|}
\hline $\begin{array}{l}\text { 9. Students can contribute effectively to the decisions made in the } \\
\text { classroom. }\end{array}$ & 4.10 & .59 \\
\hline $\begin{array}{l}\text { 10. ELT teachers' role is to raise students' awareness of other } \\
\text { varieties of English, such as Indian English and Malaysian English, } \\
\text { even if they are not addressed in the textbooks. }\end{array}$ & 2.41 & 1.01 \\
\hline Grand Mean & 3.42 & 0.88 \\
\hline
\end{tabular}

This cluster aims to gather information related to teachers' awareness of teaching and learning the English language within the CP approach. The grand mean of this cluster is 3.42 .

Items \#7 and \#8 obtained the highest means (4.32 and 4.20 respectively), indicating a high level of agreement with these statements. Teachers believed that English should be taught in English and that Arabic would hinder students' exposure to English. This is line with the study of Davari, Iranmehr and Erfani (2012), who found that the common practice of ELT teachers in Iran was to reject the first language while teaching English, which was an indication of a lack of respect for students' native language and life experiences. One can interpret this as a lack of awareness on the part of teachers about the implementation of CP in teaching and learning English to empower students through giving them voice and power, maintaining their identity, enhancing their feelings of self-esteem, reducing their feelings of anxiety, eliminating their feelings of inferiority and marginalization resulting from a lack of proficiency in the target language, and facilitating their learning and acquisition of the target language proficiency in the most suitable ways.

Item \#1 obtained a high mean as well (4.11), showing that teachers tended to agree with this view. The participants believed in Item \#1 that the role of the ELT teacher was to transfer the language to the students, which is counter to the principles of CP. CP promotes engaging in dialogues with the students and utilizing a problem solving model for reflection purposes. Teachers' lack of knowledge here is possibly due to a lack of awareness and education about the principles of $\mathrm{CP}$.

Alternatively, this could be the case due to working in a rigid, controlled, and centralized exam-based system, which marginalizes, subordinates, and suppresses and oppresses critical thinking, while promotes, encourages, and emphasizes the memorization of selective knowledge as a means of success in life.

Therefore, in-service teacher education programs should concentrate on helping teachers to realize the broader dimensions of their role as educators, not only as instructors who need to acquire academic skills that help them to perform teaching. This can be achieved through engaging teachers in "ongoing philosophical discussions about what education is" (Troudi, 2005, p.119) including 
questions such as: Is education a job or a moral act? Does it require skills, passions or both? Is technical knowledge enough for English teachers or do they need to be aware of socio-political issues surrounding English? In addition, topics such as ELT as a political enterprise, English varieties, English ownership, monolingual fallacy, native fallacy, critical literacy, dialogic teaching, and other critical topics should be at the heart of in-service teacher education programs.

By contrast, teachers believed in Item \#9 (with a mean of 4.10) that students could contribute effectively to the decisions made in the classroom. Item $\# 2$, item \#3 and item \#4 had lower means than the aforementioned item, but they were still above the mid-point of 3.0 on the 5-point scale, indicating a moderate level of agreement. These three items spelled out students' effective contribution to decision making in the classroom. Their mean scores were 3.63, 3.52, and 3.49 respectively. These items showed that the teachers' perceptions of teaching and learning were close to $\mathrm{CP}$ since teachers believed that students should be given a voice in setting the rules in the classroom, they should not be receptive of what teachers were telling them, and that good students were not the ones who obeyed the rules.

Interestingly, Item \#6 obtained a mean score of 3.86, which shows that ELT teaching in these four HE institutions tended to be based on the Communicative Language Teaching (CLT) approach. Thus, one can argue that items \#9, \#2, \#3, \#4, and \#6 are largely interrelated since an approach like CLT promotes student-centeredness and respects and values students' voices as a means of enhancing their self-esteem and reflective skills and abilities. CLT additionally empowers teachers, values them as informed and dynamic decision makers, and encourages them to research, analyze, and prioritize their students' needs, preferences, and interests and work towards meeting them. It is important that teachers at the ELCs are aware of the awakening period in TESOL, which should stimulate and drive them to support their students through teaching for social justice and social transformation, which can be achieved through adopting an approach like CLT. CLT invites teachers to adopt a critical stance towards all aspects of ELT, including their students' needs, preferences, and interests, which should help them to develop as better practitioners and professionals.

Conversely, item \#5 and item \#10 obtained the lowest means in this cluster (2.41 and 2.71 respectively), which were below the mid-point of 3.0 on the scale. Thus teachers thought that students were incapable of deciding for themselves what to learn in an ELT classroom (item \#5). This is probably one of the challenges of $\mathrm{CP}$ since the enculturation and socialization processes students in Oman experience have been negative across the board. In other words, students in the Omani (ELT) education system and according to Al-Issa (2014) are disempowered and underprivileged agents with hardly any voice. Decisions are always made on their behalf by what can be labeled as the "custodians", "guardians", or "gatekeepers" of 
(ELT) education such as teachers, for example. Due to its rigidity and control and ideological nature, education in Oman in general has fostered and enhanced total reliance by students on teachers. Students are viewed as empty vessels almost across the board and that their heads need to be filled with the knowledge their teachers hold and which in most cases represents the mandated textbook. These concepts and practices sabotage the meaning and value of knowledge as perceived at the present time and defeat the purpose of CLT and the designated roles teachers are assigned to play as learning managers, directors, and facilitators. Teachers in the ELCs are expected and required to accept challenges, take on new roles, and show awareness about the ideological and political aspects governing and driving TESOL in Oman to introduce a new culture characterized by student empowerment and critical and autonomous learning to influence change and transformation.

An appropriate model for lessons where $\mathrm{CP}$ is implemented can be hence demonstrated in a critical professional development session by an expert or a teacher who is knowledgeable about and practices CP. Such a lesson model where $\mathrm{CP}$ is utilized could also be provided through team teaching between teachers and various experts. Furthermore, during these meetings, teachers could present articles that discuss any issues related to implementing CP and teachers could then be engaged in shared readings where they read together, critically discuss the usefulness of the articles and the challenges they may face if they implement the methods in the articles (Kiely \& Davis, 2010). Teachers can also discuss how they could overcome the challenges. For instance, teachers can pick a common concern related to $\mathrm{CP}$ and conduct a collaborative discussion where a dialogic and discursive atmosphere is promoted through teachers' creativity and ability to suggest ways to overcome such challenges.

In addition, these teachers asserted that raising students' awareness of other varieties of English (item \#10) was not one of the teachers' roles. This is in line with Bieswanger's (2008) study which found that addressing varieties of English was regarded by some teachers as unimportant, since this aspect did not play a great role in important exams. Furthermore, most ELT materials emphasized the American and British varieties, which could have affected those teachers' beliefs.

Teachers, this way, are giving the American and British varieties absolute supremacy and power over the other varieties that have made English today a Language of Wider Communication (LWC), global lingua franca, and the world's first and favorite international language. By marginalizing and subordinating other important varieties, teachers are indirectly asserting and legitimizing the hegemony of the American and British varieties, which can have negative implications for their teaching as critical pedagogues with substantial awareness about the political role of TESOL today and the ideologies surrounding and shaping this role. Millions of people today reject ownership over English by the English speaking countries and consider it as a global language equally shared and used by the world 
community rather than a language of the native English speaking countries. It is noteworthy that Indian English, for example, is powerfully present in Oman due to the fact that there is more than half a million Indians in Oman, which is a large number when compared to the overall population of the Sultanate, which is just over 4.5 millions. In fact, many of those Indians are intellectuals who hold high profile positions in the private sector. They have contributed to Oman's economic advancement and the maintenance of English in the country through the use of Indian English, which is a distinct variety of English and which has different phonological, morphological, lexical, and syntactic characteristics to the other English varieties.

Bieswanger (2008) was thus critical of the fact that "varieties of English are not adequately represented in current ELT" (p. 43). He suggested rethinking the function of English as an international language in the ELT classroom and viewed the issue of teaching which variety in a changing and increasingly globalized world as a challenge and has implications for preparing $21^{\text {st }}$ century students for today's prevailing sociolinguistic realities in order to cope with their lives and communicate competently in English in as many situations as possible. Bieswanger (2008) and Farrell and Martin (2009) advocated that teachers should take responsibility for incorporating component about different World English's or English varieties and training their students to communicate effectively with speakers of varieties other than the American and British to increase their knowledge awareness and enable them to communicate effectively in a variety of situations. Farrell and Martin (2009) thus suggested teachers include three considerations in their instruction. First, they should carefully consider their teaching contexts and be culturally sensitive to the diversity of contexts in which English is taught and used. Second, they should help learners understand that their own English is valuable although it may differ significantly from what is presented in class. Third, teachers should prepare students for future encounters through exposing them to World English's available on the Internet, radio, TV, and newspapers from around the world. Additionally,

teachers should focus on teaching strategic and intercultural competence skills which will help learners be able to adjust their speech in order to be intelligible to interlocutors from a wide range of [first language] backgrounds, most of whom are not inner circle native speakers ( $p .5)$.

Matsuda (2003) and Bieswanger (2008) held teacher training programs responsible for failing to provide appropriate training for prospective teachers to address or cope with variety-related issues in the classroom. Bieswanger (2008) proposed making "adequate variety-related training a mandatory part of English language programs at universities" (p. 43). 
Research Question \#3: What are the perceptions of the English language teachers at the ELC of four Omani HE institutions about the English language curriculum within the CP approach?

\begin{tabular}{|c|c|c|}
\hline Statement & Mean & SD \\
\hline $\begin{array}{l}\text { 11. Good ELT textbooks are the ones which are } \\
\text { free of controversial issues. }\end{array}$ & 3.45 & .91 \\
\hline $\begin{array}{l}\text { 12. Equipping students with skills to find a job is } \\
\text { the main purpose of ELT. }\end{array}$ & 3.68 & 1.11 \\
\hline $\begin{array}{l}\text { 13. English is privileged compared to other } \\
\text { languages. }\end{array}$ & 4.12 & .89 \\
\hline $\begin{array}{l}\text { 14. Testing is the best way to assess students in } \\
\text { ELT. }\end{array}$ & 3.51 & 1.01 \\
\hline $\begin{array}{l}\text { 15. Quizzes and tests objectively measure } \\
\text { students' ability in English. }\end{array}$ & 3.52 & .91 \\
\hline $\begin{array}{l}\text { 16. TOEFL/IELTS is a good indication of } \\
\text { students' English proficiency. }\end{array}$ & 3.86 & 1.02 \\
\hline $\begin{array}{l}\text { 17. ELT textbooks designed by Omani experts } \\
\text { will not be as good as the ones designed by } \\
\text { native English experts. }\end{array}$ & 2.67 & .81 \\
\hline $\begin{array}{l}\text { 18. ELT should aim to create a change in } \\
\text { students' lives. }\end{array}$ & 4.12 & .91 \\
\hline $\begin{array}{l}\text { 19. Aspects of the Western lifestyle included in } \\
\text { the imported ELT instructional materials can } \\
\text { gradually interest the Omani students in Western } \\
\text { ways of life. }\end{array}$ & 3.35 & .80 \\
\hline $\begin{array}{l}\text { 20. The topics in ELT materials should be based } \\
\text { on the students' specific history and contexts. }\end{array}$ & 3.32 & 1.08 \\
\hline $\begin{array}{l}\text { 21. The ELT materials should make students } \\
\text { aware of other varieties of English, such as } \\
\text { Indian English and Malaysian English. }\end{array}$ & 2.10 & .95 \\
\hline Grand Mean & 3.42 & .95 \\
\hline
\end{tabular}

Table 4 .Teachers' Perceptions of the English Language Curriculum

Item \#13 and Item \#18 received the highest mean score (4.12). Regarding the former, English was considered to be privileged compared to other languages, can be ascribed to the fact that, currently in Oman, English is a prerequisite for joining $\mathrm{HE}$ institutions, acquiring science and technology, and getting white-collar jobs (Al-Issa, 2014). It is also interlinked with the discourse of nationalization, modernization, and prestige (Abdel-Jawad \& Abu Radhwan, 2011). In fact, Item \#12, which had a mean of 3.68, complements Item \#13. It indicated some measure of overall agreement. To some extent, then, the responding teachers thought that the main purpose of ELT was to equip students with the skills to find a job and achieve a better future. Regarding Item \#18, participants in this study agreed quite 
strongly that teaching English should aim to create a change in students' lives. This is in line with Benites (2012), who maintained that ELT should aim towards creating a change in students' lives in conjunction with improving their language.

"Change" here should be more concerned with discussing topics such as employment equity and changing social identity, for example, that lead students to find ways to articulate their problems and claim their rights in the society within the Arab Spring (Omani Awakening) context, for example, which tried to raise students' awareness about the local social, political, and economic problems and resist marginalization and promote participation in society, community, and politics.

Therefore, teachers at the ELCs and in this given complex context are expected and required to prepare their students for their future careers through adopting teaching approaches and styles and selecting and modifying appropriate topics and tasks to address their students' direct language needs and raise their awareness about such critical issues. Such effort on the part of the teachers can facilitate transforming those students into active and dynamic knowledge acquirers and become agents of social change and reform.

Also, item \#16 had a reasonably high mean (3.86). Teachers considered the IELTS and TOEFL, which are products of the UK and the USA respectively, as fairly good indicators of students' proficiency. Several authors highlighted the economic and political ideologies underlying the IELTS and TOEFL (Khan, 2009; Templer, 2004), their cultural biases and unsuitability for different contexts (AlIssa, 2016; Khan, 2009; Templer, 2004), their lack of validity (Al-Malki, 2014; Freimuth, 2016) and reliability (Alshammari, 2016). Hence, teachers at the ELCs need to be aware of these critical issues and their potential consequences and work towards utilizing alternative assessments since these two tests are high-stakes tests and much rests on the scores students obtain (Al-Issa, 2016).

Item \#15 and item \#14 had only slightly high means (3.52 and 3.51 respectively). This shows some degree of monopolization of mainstream ELT methods where testing is seen as the best way to assess students objectively in ELT. This can be attributed to the fact that quizzes and tests have been given far more weight than other forms of assessment in the four HE institutions. Al-Issa (2007) and Al Mammari (2011) contended that the testing culture, with its traditional forms of questions such as multiple-choice, fill-in-the-gaps, and matching, had dominated and controlled the ELT system in Oman for decades. By stressing the values of tests, teachers at the ELCs are legitimizing criterionreferenced assessment at the expense of other more performance-based assessment types, which test students' critical thinking skills and encourage them to use the language communicatively. For the past five decades or so the former category of assessment has dominated the Omani education scene in general and affected students' beliefs about the nature of English as a communicative tool used for 
achieving multiple purposes. Students in Oman have considered English as a factbased subject, which needs to be memorized. Formal tests have been the only benchmark for success and merit in the Sultanate. Success in English has been synonymous with the quantity of lexical and structural items memorized and used in prescribed and predefined contexts. Students have further looked at knowledge provided by the mandated textbooks and teachers as sacred, infallible, and superior to all other forms of knowledge (Al-Issa, 2007). Teachers, who are expected to be effective change agents have generally relinquished their skills and competence, become textbook-slaves, and taught-to-the-test, which has sabotaged the concept of language as a creative and innovative instrument, relegated the students' needs and interests to a secondary place, and had economic repercussions (Al-Issa, 2014).

Therefore, the assessment system in the four colleges, which relies heavily on testing, should be reformed to enable the implementation of studentcenteredness and co-operative curriculum that "promote critical thinking instead of standardized or short-answer tests" (Shor, 1992: 144). Some aspects of critical language testing need to be adopted. For instance, alternative assessments, such as a portfolio, would be given equal weight in students' final grades, which would not depend on one final test to determine their ability and future. Another idea is to use group projects as a way to assess students via asking them to examine issues related to their lives and to think about ways to ameliorate their situations. Also, an assessment should include both formative and summative assignments and should be used to inform teaching, not only to measure students and filter them.

However, item \#19 and item \# 20 had a lower mean than the last two items (3.35 and 3.32 respectively) but still above the mid-point of the scale. Teachers thought that aspects of the Western lifestyle included in the imported ELT instructional materials could gradually interest the Omani students in the Western ways of life (item \#19). This is in line with the findings of King (2012) and Karmani (2010), who asserted that the content of ELT textbooks used in HE institutions was highly political and led to transfer of western values and ideologies.

Teachers at the ELCs, hence, need to be aware of the biases in the mandated textbooks and not to privilege one culture over another and market the native English speaking countries culture at the expense of the local culture. English in Oman has specific purposes to serve; developing interest in the Western culture, which may lead to a loss of culture and identity, as reported by Hopkyns (2014) about the United Arab Emirates (UAE), which shares borders with Oman is not one of them. Hopkyns (2014) warned that globalization, which heavily relies on English as its powerful driving force has caused cultural fragility to the UAE context. Hopkyns (2014) concluded her study by recommending that since English is a "double-edged sword" in the region, teachers in the Gulf universities should show more sensitivity to their students' views about the English language, which is 
growing in dominance and affecting their identity positively and negatively, and address their needs and concerns by adding local cultural content in many forms to their teaching such as "using local newspapers in lessons and centering projects around relevant and culturally accessible topics" (p. 12). The researcher maintained that this should help learners take ownership of the language leading to improved commitment to language learning.

Additionally, the teachers in this study deemed that the topics in the ELT materials should be based on the students' specific history and contexts (\#20). This item received a mean of 3.32. This finding is consistent with the findings of Davari, Iranmehr and Erfani (2012), who reported that Iranian teachers believed that ELT materials should be based on the students' contexts. Likewise, Akbari (2008) stated that localizing the ELT materials enables learners to ponder about the society where they live and think about ways to change it. This is because addressing local concerns makes learners feel connected to what they learn. Hopkyns (2014) recommended that it would be preferable if teachers added local cultural content in their "regionally themed textbooks, which are becoming increasingly popular" (p. 12) to support and emphasize local standards and values through critical inquiry and informed action, give an edge and power to students' interests, feelings, experiences, and perceptions, help students "feel a degree of ownership towards the target language" (Hopkyns, 2014, p. 13), improve their attitudes, and increase their commitment to learning the target language.

On the other hand, Item \#21 and Item \#17 obtained the lowest means in this cluster (2.10 and 2.67 respectively), indicating some measure of disagreement with the statements. Regarding item \#21, participants tended to believe that the ELT materials should not make students aware of other varieties of English. There are several reasons for these responses. For example, in the case of many ELT programs, most textbooks do not represent the status of English as an international language (Caukill, 2011) and highlight American and British varieties as standards that indigenous learners should meet, which is true of Oman.

In addition, being aware of other varieties of English is not addressed in the exams that students take (Bieswanger, 2008). However, from the CP perspective learners "have to develop sensitivity to more than one variety of English" (Kachru \& Smith, 2008, p. 182). Therefore, TESOL teachers need to understand that, by emphasizing center standards they are perpetuating Western hegemony and marginalizing other varieties of English.

Oman has multiple English varieties, which are used communicatively. A good example is Filipino English, which has its own traits, characteristics, and peculiarities. There are more than 50,000 Filipinos guest workers in Oman. They are found in large numbers in the public and private sectors. They use English to communicate with the locals and expatriates in places such as HE academic 
institutions, schools, hospitals, showrooms, restaurants, service companies, supply chain companies, small and large businesses, retail shops, and more. These places require different genres of communicative English and reflect the spread, maintenance, and ownership of English by non-native English speaking individuals, who need English as an international language, LWC, and global lingua franca mainly for economic purposes. Students hence need to be exposed to this variety to see genuine uses, values, and representations of English beyond the Western world and hegemony.

Matsuda (2003) was thus critical of teaching materials lacking representation of World English's. She suggested incorporating more characters, pictures, and topics from the outer and expanding circles in the used materials. The author suggested addressing some common global issues such as "history, nature, health, human rights, world peace, and power inequality" (p. 725), and discuss them in relation to "internationalization, globalization, and the spread of English" (p. 725).

Regarding item \#17, with a mean of 2.67, participants responded that ELT textbooks designed by Omani experts would not be as good as those designed by native English experts. This can be attributed to the experience Oman has undergone for the past five decades or so of importing ready-made materials from big publishers to teach English and hiring consultants from the inner circle countries to establish academic programs at HE institutions (Al-Issa, 2006; Karmani, 2010), which has perpetuated cultural dependency of the Sultanate over the English native speaking countries. Many of these imported commercially written textbooks have come under critical scrutiny by several researchers and found culturally biased, inappropriate, and discriminatory and entail hidden curriculum representing the West (Karim \& Haq, 2014; Varzande, 2015) and views of language learning (Karim \& Haq, 2014). While such textbooks promote the American and British cultures with an aim to maintain their cultural hegemony, spread their values, and format non-native English speaking learners' identities (Varzabde, 2015), they marginalize multicultural aspects as a means of enhancing learners' awareness of cultural diversity in English language learning and teaching (Nomnian, 2013). English within these textbooks is a means of suppression and oppression, mind colonization, and social and linguistic discrimination (Varzande, 2015). Hence, teachers at the ELCs need to be aware of this hidden agenda and work towards modifying, selecting, and developing methodologies and materials that meet their students' preferences and ELT education goals in the era of globalization (Nomnian, 2013).

\section{Conclusion}

This study aimed to investigate teachers' awareness of $\mathrm{CP}$ in four HE institutions in Oman. The findings showed that there was a widespread lack of awareness of the concept of $\mathrm{CP}$ among TESOL teachers. Nonetheless, there was a 
minority of teachers who were aware of $\mathrm{CP}$ with limited implementation in their classes. On the other hand, there were teachers who were aware of CP but who did not implement it due to its radical nature or due to the nature of the context that was characterized by rigid syllabuses and regulations. The results of the study also indicated that TESOL in the four HE institutions was governed by a banking model and mainstream ideologies in their perceptions towards teaching and learning and curriculum. Moreover, the results indicated that for teachers to pursue professional development, raise their awareness of sociocultural and sociopolitical complexities surrounding learning and teaching English, and transform into critical pedagogues, they will have to face many challenges and jump some hurdles pertinent to their beliefs about the theory and practice of ELT at their respective ELCs.

Nonetheless, the data showed that there was a level of criticality within the TESOL system in the four colleges including the idea that creating changes in students' life should be an aim for ELT and the students' voice should be respected in the classroom.

This study had some limitations. First, the study used a convenience sample, so its findings are limited by the unique characteristics and context of the study participants. Therefore, this is by no means representative of TESOL teachers in various HE institutions across Oman. Second, this study is limited since its design does not implement document analysis including courses' syllabi, descriptions, and the institutional and national policies pertaining to TESOL, which could have enriched its findings.

\section{References and notes:}

Abdel-Jawad, H. R. \& Abu Radwan, A. S. (2011). The status of English in institutions of higher education in Oman: Sultan Qaboos University as a model. In A. Al-Issa and L.S. Dahan (Eds.), Global English and Arabic: Issues of language, culture and identity (pp.123-151). Oxford: Peter Lang.

Abednia, A. (2012). Teachers' professional identity: Contributions of a critical EFL teacher education course in Iran. Teaching and Teacher Education, 28(5), 706-717.

Akbari, R. (2008). Transforming lives: Introducing critical pedagogy into ELT classrooms.ELT Journal, 62(3), 276-283.

Al Hajri, F. (2013).An evaluation of the effectiveness and predictive validity of English language assessment in two colleges of Applied Sciences in Oman (Doctoral dissertation). University of Edinburgh, UK.

Al-Husseini, S. (2006). The visible and invisible role of English foundation programmes: A search for communication opportunities within EFL contexts. Asian EFL Journal, 8(4), 35-51.

Al-Issa, A. (2006). The cultural and economic politics of ELT in the Sultanate of Oman. Asia EFL Journal On-line, 8(1). Retrieved from http://www. asian-efljournal.com/September_06_asmai.php

Al-Issa, A. (2007). An ideological discussion of the implications of implementing a flexible syllabus for ESL policy in Sultanate of Oman. RELC (Regional Language Centre) Journal, 38(2), 199-215. 
Al-Issa, A. (2014). Constructing grammar instruction in the Omani EFL system: A critical literacy perspective. The Qualitative Report, 19(104), 1-25. Retrieved from http://www.nova.edu/ssss/QR/QR19/al-issa104.pdf

Al-Issa, A. (2014). Constructing grammar instruction in the Omani EFL system: A critical literacy perspective. The Qualitative Report, 19(104), 1-25. Retrieved from http://www.nova.edu/ssss/QR/QR19/al-issa104.pdf

Al-Issa, A., Al-Bulushi, A. \& Al-Zadjali, R. (2016). Arab English language candidates climbing the IELTS mountain: A Qualitatively driven hermeneutic phenomenology study. The Qualitative Report, 21(5), 848-863. Retrieved from http://nsuworks.nova.edu/cgi/viewcontent.cgi?article=2367\&context=tqr

Aliakbari, M. \& Allahmoradi, N. (2012). On Iranian school teachers' perceptions of the principles of critical pedagogy. International Journal of Critical Pedagogy,4(1), 154-171.

Al-Jadidi, H. S. (2009). Teaching English as a foreign language in Oman: an exploration of English language teaching pedagogy in tertiary education, doctoral dissertation. Victoria University, Australia.

Al-Ghatrifi, Y. (2006). An Investigation into the English Teachers' Perceptions of the PRIT Course in the Sultanate of Oman (Master's thesis). University of Leeds, UK.

Al-Jardani, K. S. (2015). The need for bridging the gap between general and tertiary education in Oman.English Linguistics Research, 4(2), 45-48.

AL-Lamki, N. (2009). The beliefs and practices related to continuous professional development of teachers of English in Oman (Doctoral dissertation. University of Leeds, United Kingdom.

Al-Maamari, F. (2011).The micropolitics of assessment in EAP programmes: a critical realist perspective(Doctoral dissertation). Bristol University, UK.

Al-Mahrooqi, R. (2012). A student perspective on low English proficiency in Oman. International Education Studies, 5 (6), 263-271.

Al-Mahrooqi, R., \& Al-Busaidi, S. (2010). Meeting Local Needs in Materials Writing.Advances in Language and Literary Studies, 1(1), 91-115.

Al-Mahrooqi, R., Denman, C. \& Al Issa, A. (2015). Student perspectives of quality assurance mechanisms in an EFL program in the Sultanate of Oman. International Journal of Arts \& Sciences, 8(5), 81-106.

Al-Mahrooqi, R \& Denman. C. (2016).Proficiency and communicative competence in English and employability in the Arabian Gulf. In R. Al-Mahrooqi \& C. Denman (Eds.), Bridging the gap between education and employment: English language instruction in EFL contexts (pp.389-409).New York: Peter Lang.

Al-Malki, M. (2014).Testing the predictive validity of the IELTS Test on Omani English candidates' professional competencies. International Journal of Applied Linguistics and English Literature, 3(5), 166-172.

Al-Mekhlafi, A., \& Ramani, P. (2011). Expectation versus reality: Communicative approach to EFL teaching. Studies in Learning, Evaluation, Innovation and Development, 8(1), 98-113.

Al-Nabhani, M. (2007).Developing the Education System in the Sultanate of Oman Through Implementing Total Quality Management (Doctoral dissertation).University of Glasgow, UK.

Alshammari, M. (2016). IELTS academic reading module test: Validity and reliability. British Journal of English Linguistics, 4(2), 26-37.

Al Shmeli, S. H. (2011). Higher education in the Sultanate of Oman: Catching up rapidly. In M. Martin \& M. Bray (Eds.), Tertiary education in small states: Planning in the context of globalization (181-191).IIEP Policy Forum: UNESCO publications. Retrieved from http://unesdoc.unesco.org/images/0021/002121/212196E.pdf

Baladi, N. (2007). Critical pedagogy in the ELT industry: Can a socially responsible curriculum find its place in a corporate culture?, master dissertation. McGill University, Canada.

Banegas, D. L. (2011).Teaching more than English in secondary education.ELT Journal, 65(1), 80-82.

Benites, M. A. (2012).Critical pedagogy and English language acquisition. Polygon Spring, 74-84. 
Bieswanger, M. (2008).Varieties of English in current English language teaching. Stellenbosch Papers in Linguistics, 38, 27-47.

Bosman, C., Dedekorkut, A. \& Dredge, D. (2012). The first year experience in higher education and planning studio pedagogies: An Australian case study. CEBE Transactions, 9(1), pp. 3-19.

Braa, D., \& Callero, P. (2006).Critical pedagogy and classroom praxis. Teaching Sociology, 34(4), 357-369.

Byean, H. (2011). An Exploration for Glocalizing Critical Pedagogy in the Korean Middle School Context: Toward Critical Co-teaching Proxis Between Local and Native-English-speaking Teachers (Doctoral dissertation). University of Wisconsin-River Falls.

Caukill, E. (2011) Learning English in an English speaking world: examining opportunities for intercultural understandings and connectedness through representations of identities in English language textbooks. In A. Dashwood, \& J.B Son (Eds.), Language, Culture and Social Connectedness (pp. 57-73). Newcastle: Cambridge Scholars Publishing.

Canagarajah, A. S. (1999). Resisting linguistic imperialism in English teaching. Oxford: Oxford University Press.

Canagarajah, S. (2005a). Critical pedagogy in L2 learning and teaching. In E. Hinkel (Ed.), Handbook of research in second language teaching and learning (pp. 931-949). Mahwah, NJ: Lawrence Erlbaum Associates.

Canagarajah, S. (2005b). Conclusion. TESOL Quarterly, Vol. 39, No. 4 (Dec., 2005), pp. 745-753.

Chi, G. H. (2011).Critical pedagogy in undergraduate English writing class in Taiwan (Doctoral dissertation).Indiana University, USA.

Cox, M. 1. P., \& Assis-Peterson, A. A. d. (1999). Critical pedagogy in ELT: Images of Brazilian teachers of English. TESOL Quarterly, 33,433-484.

Crookes, G. V. (2013). Critical ELT in action: Foundations, promises, praxis. New York: Routledge.

Davari, H., Iranmehr, A., \& Erfani, S. M. (2012).A survey on the Iranian ELT community's attitudes to critical pedagogy. English Language Teaching, 5(2), 101-111.

Derince, Z. (2011). Language learning through critical pedagogy in a "Brave New World". International Review of Education, 57(3-4), 377-395.

Farrell, T. \& Martin, S. (2009). To teach standard English or world Englishes? A balanced approach to instruction. English teaching Forum, 2, 2-7.

Freire, P. (2000). Pedagogy of the oppressed. Bloomsbury Publishing.

Freire, P. (2003). From pedagogy of oppressed. In A. Darder, M., Baltodano \& D. R. Torres (Eds.), The Critical pedagogy reader (pp.57-68). New York: Routledge Falmer.

Freimuth, H. (2016). An examination of cultural bias in IELTS Task 1non-process writing prompts: A UAE perspective. Learning and Teaching in Higher Education: A Gulf Perspective, 13(1), 1-16.

Garcia-Gonzalez, R. (2000). Is it a Dream? Critical pedagogy in bilingual, elementary classrooms. Paper presented at Annual Meeting of the American Educational Research Association, New Orleans, LA.

Gruenewald, D. (2003). The best of both worlds: A critical pedagogy of place. Educational Researcher, 32(4), 3-12.

Haque, E. (2007). Critical pedagogy in English for Academic Purposes and the possibility for 'tactics' of resistance. Pedagogy, Culture \& Society, 15(1), 83-106.

Hargreaves, A. (1994). Changing teachers, changing times: Teachers' work and culture in the postmodern age. Teachers College Press.

Hopkyns, S. (2014). The effects of global English on culture and identity in the UAE: A doubleedged sword. Learning \& teaching in Higher Education: Gulf Perspectives, 11(2), 1-20.

Ismael, D. A. (2013).The influence of TESOL teacher assessment literacy on the ethicality of English language assessment and the position of Kurdish TESOL teachers. International Journal of Bilingual \& Multilingual Teachers of English, 1(2), 91-104.

Ismail, A. (2011). Language planning in Oman: Evaluating linguistic and sociolinguistic fallacies (Doctoral dissertation). Newcastle University, UK.

Karim,S. \& Haq, N. (2014). Culture of language learning: A comparative study of English language textbooks used in Pakistan. Journal of Language \& Linguistic Studies, 10(2), 157-168. 
Kachru, Y. \& Smith, L. E. 2008.Cultures, Contexts, and World Englishes. New York: Routledge.

Karmani, S. (2010).On perceptions of the socialising effect of English medium education on students at a gulf Arab university with particular reference to the United Arab Emirates (Doctoral dissertation). University of Exeter, UK.

Karimpour S. and Yaqubi Bayer .(2017). Teachers' Understanding-Check Practices and Learners' Following Orientations in EFL Classroom Interaction: A Conversation Analytic Study.Khazar Journal of Humanities and Social Sciences,Vol 20,№3,.Baku , Azerbaijan,2649

Keesing-Styles, L. (2003). The relationship between critical pedagogy and assessment in teacher education. Radical Pedagogy, 5(1), 1-20.

Khan, S. (2009). Imperialism of international tests: An EIL perspective. In Sharifian, F. (Ed.), English as an international language: Perspectives and pedagogical issues (pp. 190-287). Bristol: Multilingual Matters.

Kiely, R., \& Davis, M. (2010). From transmission to transformation: Teacher learning in English for speakers of other languages. Language Teaching Research, 14(3), 277-295.

King, S. R. (2012). Purposeful or careless: Critical discourse analysis of a unit of an EFL listening textbook text and image. Oman Journal of English Language Teaching, 19-44.

Ko, M. \& Wang, T. (2009). Introducing Critical Literacy to EFL Teaching: Three Taiwanese College Teachers' Conceptualization. The Asian EFL Journal Quarterly, 11(1), 174-191.

Kohli, R., Picower, B., Martinze, A., \& Ortiz, N. (2015). Critical professional development: Centering the social justice needs of teachers. International Journal of Critical Pedagogy, 6(2), 7-24.

Kumaravadivelu, B. (2003). A postmethod perspective on English language teaching. World Englishes, 22(4), 539-550.

Kumaravadivelu, B. (2006). TESOL methods: Changing tracks, challenging trends. TESOL Quarterly, 40(1), 59-81.

Kumaravadivelu, B. (2011). Language teacher education for a global society: A modular model for knowing, analyzing, recognizing, doing, and seeing. New York: Routledge.

Lin, A. M. Y. (2004). Introducing a critical pedagogical curriculum : A feminist reflexive account. In B. Norton \& K. Toohey (Eds.), Critical pedagogies and language learning (pp. 271 - 290). New York: Cambridge University Press.

Lynch, B. K. (2001). Rethinking assessment from a critical perspective. Language Testing, 18, 351372.

Mack, L. (2012). Does every student have a voice? Critical action research on equitable classroom participation practices. Language teaching research, 16(3), 417-434.

Mazier, M. (2014).Beyond the neoliberal imaginary: investigating the role of critical pedagogy in higher education (Doctoral dissertation). University of Western Ontario, Canada.

Matsuda, A. (2003). Incorporating world Englishes in teaching English as an international language.

TESOL Quarterly 37(4), 719-29.

McLean, A. C. (2011). Particularity, practicality and possibility: an investigation into the awareness and use of communicative language teaching methodology in a college of higher education in Oman (Master's thesis). University of South Africa, South Africa.

Mohd-Asraf, R. (2005). English and Islam: A clash of civilizations? Journal of Language, Identity, and Education, 4(2), 103-118.

Mohamed, A. A., \& Malik, A. (2014). ELT Teachers' Awareness of Critical Pedagogy: A CrossCultural Study. Journal of ELT and Applied Linguistics (JELTAL), 2(3), 13-27

Moody, J. (2012). A critique of the concept of EFL in the Arabian Gulf countries. In A. Mahmoud, \& R. Al-Mahrooqi (Eds), Issues in Teaching and Learning English as a Foreign Language in the Arab World (pp.9-32). Muscat: Sultan Qaboos University's Academic Publications Board.

Moorhouse, B. L. (2014). Using Critical Pedagogies with Young EFL Learners in a Hong Kong Primary School. International Journal of Bilingual \& Multilingual Teachers of English. 2(2), 79-90. 
Noroozisiam, E., \& Soozandehfar, S. M. A. (2011). Teaching English through critical pedagogy: Problems and attitudes. Theory and Practice in Language Studies, 1(9), 1240-1244.

Neumann, J. W. (2013). Advocating for a more effective critical pedagogy by examining structural obstacles to critical educational reform. The Urban Review, 45(5), 728-740.

Nomnian, S. (2013). Thai cultural aspects in English language textbooks in a Thai secondary school. Veridian E-journal, 6(7), 13-30.

Norton, B. (2000). Language, identity, and the ownership of English. TESOL Quarterly, 31 (3), 409429.

Norton, B. \& Toohey, K. (2004). Critical Pedagogies and language learning: An Introduction. In Norton, B. \& Toohey, K. (Eds.), Critical pedagogies and language learning. (pp. 1-19) Cambridge: Cambridge University Press.

Ó‘Móchain, R. \& Perkins, R. (2010). Critical issues: A survey of topic popularity among university students. The language teacher, 34 (4), 5-11.

Ooiwa-Yoshizawa, A. (2012). Implications of EFL critical pedagogy: Theory, practice and possibilities. Keiwa Bulletin, 21, 21-30.

Pennycook, A. (2001). Critical applied linguistics: A critical introduction. Mahwah, NJ: Lawrence Erlbaum.

Peterson, R.E. (2003). Teaching how to read the world and change it: Critical pedagogy in the intermediate grades. In A. Darder, M. Baltodano, \& R. D. Torres, (Eds.), The critical pedagogy reader (pp.365-387). Great Britain: Routledge Falmer.

Pishghadam, R., \& Naji Meidani, E. (2012). A critical look into critical pedagogy. Journal for Critical Education Policy Studies, 10(2), 464-484.

Sadeghi, S. (2008). Critical pedagogy in an EFL teaching context: An ignisfatuus or an alternative approach. Journal for critical education policy studies, 6(1), 277-295.

Sadeghi, S., \& Ketabi, S. (2009). From liberal ostrichism to transformative intellectuals: An alternative role for Iranian critical pedagogues. Journal of English Language Teacher Education and Development12, 52-60.

Safari, P., \& Pourhashemi, M. R. (2012). Toward an empowering pedagogy: Is there room for critical pedagogy in educational system of Iran? Theory and Practice in Language Studies, 2(12), 2548-2555.

Sahragard, R., Razmjoo, S. A., \& Baharloo, A. (2014). The practicality of critical pedagogy from Iranian EFL instructors' viewpoints: a cross sectional study. The International Journal of Critical Pedagogy, 5(2), 178-193.

Shin, H. \& Crooks, G. (2005).Exploring the possibilities for EFL critical pedagogy in Korea: A twopart case study. Critical Inquiry in Language Studies: An International Journal, 2(2), 113136.

Shor, I. (1992). Empowering education: Critical teaching for social change. Chicago: University of Chicago Press.

Shor, I. (1996). When students have power: Negotiating authority in a critical pedagogy. Chicago, IL: The University of Chicago.

Tanveer, M. (2013).The Factors causing English language and study skills gaps between foundation and undergraduate programmes; an exploratory study at Majan College. Asian EFL Journal, 15 (3), 161-200.

Templer, B. (2004). High-stakes testing at high fees: Notes and queries on the international English proficiency assessment market. Journal of Critical Educational Policy Studies, 2(1): 189226.

Troudi, S. (2005).Critical content and cultural knowledge for teachers of English to speakers of other languages. Teacher Development, 9 (1). 115-129

Troudi, S. (2015).Critical research in TESOL and language education. In D. Brown and C. Coombe (Eds.), The Cambridge guide to research in language teaching and learning (pp.89-98). London: Cambridge University Press.

Varzande, M. (2015). The construction of new political identities through the internationally distributed English learning textbooks. English Language Teaching, 8(2), 101-108.

Wink, J. (2005).Critical pedagogy: Notes from the real world. Boston, MA: Pearson Education, Inc. 


\title{
Summary
}

\section{Investigating TESOL Teachers' Awareness of Critical Pedagogy at Higher Education Institutions in Oman: Implications for Critical Professional Development}

\author{
Thuraya Al Riyami \\ Ibra College of Technology, Oman
}

\author{
Ali Al Issa \\ College of Education, Sultan Qaboos University, Oman
}

Critical Pedagogy (CP) has been proposed as an alternative pedagogy capable of meeting the complex demands of teaching English within a particular sociopolitical context. Despite the fact that CP has been present in education since the 1960s, much of the research on CP has been conducted recently in Teaching of English to Speakers of Other Languages (TESOL) contexts. There is a growing but as yet small amount of research that addresses the usage of $\mathrm{CP}$ in TESOL contexts, to which this study hopes to make a useful contribution. Therefore, this study investigates the extent to which TESOL teachers from four higher education institutions in the Sultanate of Oman are aware of CP. In order to achieve this, a questionnaire is administered to 178 English Language Teachers. The main findings reveal a widespread lack of awareness of the concept of CP among TESOL teachers. Nonetheless, minorities of teachers are aware of CP and implement it in a limited fashion in their classes. On the other hand, there are teachers who, whilst being aware of $\mathrm{CP}$, do not implement it. The implications of these findings are discussed.

Keywords: Critical pedagogy, Teaching English to Speakers of Other Languages, curriculum, teaching and learning 


\section{Appendix 1}

Dear teacher,

This questionnaire aims to collect data regarding your opinion about the current practice of English Language Teaching (ELT) in the higher education institutions in Oman. Your participation is voluntary and you can choose not to take part. However, your decision to participate will not only help me in my research but also provide you, as teachers experiencing the situation, with important information. Your answers are valuable in providing a deeper insight into the de facto practices, and hopefully, reflect your voice in order to improve the ELT realm in Oman. Please note that all your responses will be used confidentially for research purposes only. Estimated time to read and answer the questions will be 15 minutes.

\section{Section One}

Personal Information:

Please put $(\sqrt{ })$ next to the appropriate response:

\section{Education level:}

$\square$ Bachelor Degree

$\square$ Master Degree

$\square$ Doctorate Degree

2. Gender: $\square$ Male $\quad \square$ Female

\section{Nationality:}

\section{Section Two}

Please answer the following questions:

1. Have you heard of critical pedagogy?

If yes, where did you hear about it?

Can you define it?

Have you already used it in your teaching? 


\section{Section Three}

To what extent do you agree with the following statements?

Please put $(\sqrt{ })$ in the appropriate box

Section 1: Teaching and Learning of the English Language

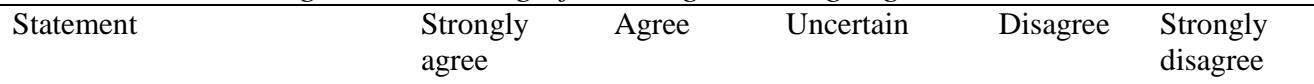

1. The role of the ELT teacher is to transfer the language to the students

2. Policies and rules should be set by the teachers and students should follow them 3. Students are receptive to what the teacher is telling them to do

4. A good student is the one who obeys rules

5. Students can decide for themselves what to learn in an ELT course

6. The ELT teaching in my college is based on the communicative English teaching approach

7. English should only be taught through English.

8. Arabic usage in the classroom hinders students' exposure to English.

9. Students can contribute effectively to the decisions made in the classroom.

10. ELT teachers' role is to raise students' awareness of other varieties of English, such as Indian English, Malaysian English, even if they are not addressed in the textbooks. 
Section 2: Curriculum of the English Language

\begin{tabular}{llllll}
\hline Statement & $\begin{array}{l}\text { Strongly } \\
\text { agree }\end{array}$ & Agree & Uncertain & Disagree & $\begin{array}{l}\text { Strongly } \\
\text { disagree }\end{array}$ \\
\hline
\end{tabular}

11. Good ELT textbooks are the ones which are free of controversial issues.

12. Equipping students with skills to find a job is the main purpose of ELT.

13. The spread of ELT should be looked at as unproblematic.

14. English is privileged compared to other languages.

15. Testing is the best way to assess students in ELT.

16. Quizzes and tests objectively measure students' ability in English.

17. TOEFL/IELTS is a good indication of students' English proficiency

18. ELT textbooks designed by Omani experts will not be as good as the ones designed by native English experts.

19. ELT should aim to create a change in students' lives.

20. Aspects of the Western lifestyle included in the imported ELT instructional materials can gradually interest the Omani students in Western ways of life.

21. The topics in ELT materials should be based on the students' specific history and contexts.

22. The ELT materials should make students aware of other varieties of English, such as Indian English, Malaysian English. 